\title{
Technical cooperation in the field of human rights
}

\author{
Farid Hamdan
}

This chapter highlights the contribution of the academic teaching which I have received at the University of London within the MA in Understanding and Securing of Human Rights in 2002-3. The course content and its themes have contributed to strengthening my knowledge and skills for the human rights field, which have enabled me to have better opportunities to contribute to human rights protection and promotion. Throughout the last years, I have worked extensively to transfer the knowledge gained into projects and practical programmes in the field of human rights, namely, capacity building through Technical Cooperation Programmes (TCPs). ${ }^{1}$ In this chapter, I will use three examples to show the contribution of TCPs in building knowledge and skills to promote and protect human rights. The first example will focus on TCPs during conflict and insecurity; the second will show building skills during transition; and the third will show the country specific programme during stability.

\section{Building capacities of rights holders and duty bearers during armed conflict}

Hawa and Ezz Eldeen were among others from Internally Displaced Persons who were trained on training-of-trainers for local communities. As a result of a series of training programmes, they were able to know their rights and the rights of others. They were also skilled on how to defend themselves and other victims during armed conflict. They have become able to understand and use human rights related terms. They have also become able to provide victims with advice, especially women victims.

1 Technical Cooperation refers to the United Nations advisory service and assistance to Governments in the field of human rights. See UN Office of the High Commissioner for Human Rights, Fact sheet No.3 (Rev.1), Advisory Service and Technical Cooperation in the Field of Human Rights, Geneva: United Nations (1996). Available at http://www.ohchr.org/Documents/Publications/FactSheet3Rev.1en. pdf (accessed 17 Sept. 2015). 
TCPs in conflict areas do not focus only on empowering victims but have also targeted duty bearers and placed both groups on its programme to protect human rights. At the same time, TCPs have targeted duty bearers from prison administrations, attorney generals and prosecutors, judges, and police investigators to promote awareness on the application of international human rights law. They also created forums for dialogue to find the best ways to improve the human rights situation in areas that have witnessed conflicts and human rights violations.

Important activities have been carried out in areas living in conflict and TCPs have had a positive impact on enhancing the role of victims in protecting themselves, albeit without improving the human rights situation or putting an end to the conflict. Such activities are varied, including:

- Organising training and awareness raising workshops on issues related to gender-based violence during the armed conflicts;

- Developing special training programmes to improve native administrations' capacities to respect gender and women's rights by promoting the concepts of equality and non-discrimination;

- Organising training programmes for governmental institutions, officials, prosecutors and judges on their role to respect human rights.

Implementing capacity building activities during armed conflict is not an easy task for many reasons. The activities are intended to target victims who are affected negatively by the conflict consequences and they are expecting you to provide them with physical protection. The existence of social traditions can be problematic; for example, traditions prohibit discussion of issues related to sexual violence, and thus you have difficulties to communicate with the victims. The last and important challenge is the high level of illiteracy among local groups.

In response, you need to exert creative efforts in order to overcome such difficulties by adopting innovative methods such as working to:

- Cooperate with the local administration and build trust with them in order to get access to victims;

- Work cooperatively with international organisations working on the ground, especially those who provide relief services;

- Enhance victims' participation, which requires efforts to show the positive impact of their participation;

- Adopt a simplified training approach based on role play and showing films to overcome the illiteracy issue;

- Provide pick up for participants from their locations to the training venue and provide a secure venue for training;

- Provide a place for breastfeeding mothers to feed their infants.

TCPs are not replacing activities of human rights monitoring and reporting but rather they complement these. From an individual experience, technical cooperation programmes have contributed in building the capacities of duty 
bearers to know their responsibilities and obligations at the same time it has contributed in raising victims' awareness in understanding their rights and thus their ability to defend them.

\section{Training of journalists on a Human Rights-Based Approach (HRBA) for media coverage: Middle East and North Africa}

In working to mobilise important groups to protect and promote human rights, I would like to reflect on my works and engagement with journalists and prominent media institutions in the Middle East and North Africa (MENA) region to promote and protect human rights. A training programme has been developed in partnership with different media institutions ${ }^{2}$ and in cooperation with the UN Training and Documentation Centre for South West Asia and the Arab Region. The programme aimed at building the capacities of journalists on how to report human rights stories from a perspective of human rights.

From 2010 to 2015 the partners have organised a yearly programme for journalists for the MENA region. They were trained on the content of international human rights law, basic human rights conventions and additional optional protocols, obligations of the state to respect human rights, and how journalists can benefit from the protection provided by international human rights law. They were also sensitised to relevant alarming human rights issues in the MENA region, like the status of freedom of expression and it's relation to the work of a journalist, the right to access information, and the concept of transitional justice, as many countries in the region are going through transitional justice processes to deal with past human rights violations and crimes.

Journalists have also been provided a technical training on the content of HRBA, as in each story they have to reflect relevant international human rights conventions, and the concepts of non-discrimination, participation, and promotion of the rule of law. In the beginning, targeting journalists was a difficult and challenging task. Many academic and educational institutions do not provide human rights teaching for journalists during their university or training phases. The majority of teaching and training received has focused on building skills for journalistic coverage without linking this to human rights. Even a journalist who is not oriented as a human rights defender has a moral responsibility to promote and protect human rights.

The recent approach which has been adopted by many media institutions such as the $\mathrm{Al}$ Jazeera channel has a tangible contribution in promoting the role of journalists in human rights protection. In addition, the presence and belief

2 These include the Doha Centre for Media Freedom (http://www.dc4mf.org/ar) and Public Freedoms and Human Rights at Al Jazeera (http://www.aljazeera.net/news/ humanrights). 
of persons ${ }^{3}$ who have a human rights background in addition to their work within these institutions has also provided additional opportunities to support the involvement of journalists in human rights issues.

The organisation of continuous yearly training programmes has resulted in creating individuals and groups of professional journalists in different media outlets in the region who are active contributors in promoting human rights. They are active journalists in newspapers like El Ghad, Al Quds, Annahar, ALQabas, Al Jazeera channel and other news agencies in Yemen, Sudan, Egypt and Algeria. ${ }^{4}$

Today, those trained journalists are forming themselves into networks and groups using social media to communicate and share information between them. They have also produced very strong media reports and stories, covering many important human rights issues such as child protection, combating trafficking, the status and condition of prisons, rights of women in education, the right to health and the right to education. In doing so, journalists have reflected clearly the language of human rights by using precise terms and making references to many human rights conventions and UN bodies.

\section{Building national capacities in the field of human rights: Kingdom of Saudi Arabia}

A TCP entitled 'Enhance national capacities to promote and protect human rights's has been signed and agreed between the UN Office of the High Commissioner for Human Rights and the Kingdom of Saudi Arabia through the Saudi Human Rights Commission (SHRC). ${ }^{6}$

In its first year, the programme has carried out a series of promotional human rights activities that targeted both governmental bodies and civil society actors. A five day programme focused on the international system of human rights and its protection mechanisms has been carried out and aimed at enhancing better engagement between Saudi Arabia and the UN human rights system. The launch of the training programme was well received and got proper media coverage. It was an encouraging step to go ahead with other planned

3 A prominent role has been played by Dr. Hassan Mujamer, who is a Producer for the $\mathrm{Al}$ Jazeera channel, to support the engagement of journalists in human rights programmes and activities.

4 See the El Ghad newspaper in Jordan http://www.alghad.com; AlQuds newspaper http://www.alquds.com; Annahar http://www.annahar.com; AlQabas http://www. alqabas.com.kw.

5 A memorandum of Understanding has been signed between OHCHR and Saudi Arabia in 2012. The purpose is to build national capacities through a three-year work plan.

6 The Saudi Human Rights Commission is not accredited by the International Accreditation Committee - ICC. 
activities. In Saudi Arabia and other countries, the availability of political will is a crucial step to plan and implement activities related to the promotion and protection of human rights.

Other subsequent activities focused on very important issues related to combating human trafficking, and the reporting mechanism for the UN Committee on the Elimination of Racial Discrimination and the UN Committee on the Elimination of Discrimination against Women. The first year of the project was concluded by organising a training-of-trainers programme which resulted in having 20 trainers, constituted by ten female and ten male participants.

The first year of implemented activities has paved the way for more constructive activities. Two training activities have targeted separately researchers working in the offices of the SHRC and another workshop for civil society activists on how to monitor and report human rights issues in Saudi Arabia. At the time of writing these lines, the project is in the last stages to organise a three day training workshop on the drafting process of the State periodic report for the Committee on the Elimination of Racial Discrimination.

\section{Conclusion}

Technical Cooperation Programmes have an important role in promoting and protecting human rights. They could be implemented during the time of conflict or in a stable situation. Countries also play an important role in fully cooperating with TCPs and not imposing restrictions to hinder its goals and objectives. To make TCPs successful, the concerns and needs of victims should be considered. This requires a measure to build trust with victims or those affected by the conflict. TCPs also should take into consideration social circumstances especially when tackling issues and programmes to combat sexual violence against women because in some societies discussing such issues is a taboo.

TCPs normally face various difficulties in both stable and non-stable countries, especially when there is doubt on the idea of human rights, or the idea of human rights clashes with culture, religion and other traditions. However, numerous experiences of TCPs should be discussed, studied and further researched as part of the requirements of academic programmes. This will identify reasons of success and failure especially in countries which are in transition or in conflict, because where there is a conflict, there will be victims of human rights.

As an individual and in order to achieve success in carrying out tasks and responsibilities within TCPs, there is a need to be equipped with a solid knowledge of human rights, and have multiple protection skills and a good understanding of the international system for human rights protection. In this regard, the MA in Understanding and Securing Human Rights has provided 
me with three main elements: 1) the idea of human rights and its historical philosophy and development; 2) techniques and skills for protection; and 3) familiarity with the UN human rights system. 